\title{
Mobile-Assisted on Extensive Reading: Students' Voices
}

\author{
Dzurriyyatun Ni'mah', Atik Umamah' \\ Universitas Islam Malang, Indonesia \\ 11dzurriyyatun@unisma.ac.id, zatikumamah@unisma.ac.id
}

\begin{abstract}
As reading starts to lose its popularity for most students, digital reading can serve as a solution to overcome this problem. The integration of digital reading and extensive reading practice can be beneficial for language learners. A number of researchers have conducted the studies on this issue through different perspectives. The current study mainly focuses on the students' perception of digital reading in extensive reading practice. The qualitative approach was employed to obtain the research data. Therefore, series of questions were addressed to achieve the research objective through an openended interview. The result showed that the students have positive attitudes towards digital reading when they have to read extensively. The practicality, portability, flexibility, accessibility, and affordancesof e-books helped them to apply extensive reading successfully. Moreover, extensive reading benefits the students to develop their reading habit, discover pleasure in reading, as well as improve other skills in English.
\end{abstract}

Keywords: digital reading, extensive reading, students' perception

\section{INTRODUCTION}

To succeed in acquiring second language mastery, an effective reading is essential, because, after all, reading is the basis instruction in all aspects of language learning (Mikulecky, 2008). Unfortunately, most students assume reading as an unpleasant activity. In contrast with this reality, the university students must take the reading skill courses from semester 1 to semester 4 , where they are "forced" to read any text types. Most of texts are related to academic purposes. As the content does not match with the students' field of study and interest, the reading activity, gradually, loses the popularity in the students' eyes and finally becomes boring (Safaeia\&Bulca, 2013). For this reason, it is needed to immediately find the solution to make reading much more interesting and enjoyable for students. Here, Extensive Reading (ER) is introduced to the students to overcome this problem.

Extensive reading is an approach of teaching and learning a foreign language through reading texts or books that are chosen personally by the students and guided by the instructors (Day\& Bamford, 1998). In addition, Stanley (2005) proposed that extensive reading let the students to read more texts for understanding and enjoying them. Mobile device, actually, can facilitate extensive reading practically and easily. Digital reading or e-books offer the practicality, easiness, portability, and affordances to the students. Having 24-hour access to online library enables them to obtain any e-book they wanted and start reading 
immediately. Most mobile-based reading software allows readers to customize their reading experience, for example, tailoring font size, style and screen layout (Huang, 2013). Considering these benefits, mobile devices could make the extensive reading experience more attractive (Milliner \& Cote, 2015).

Some related studies about this concern showed the positive result on the use of mobile device in extensive reading. Milliner and Cote (2015) revealed that most students had favorable opinion of online reading and reading on their smartphones. It is in line withLin's (2014) findingwhich showed that the group of students who read using tablet achieved better result both in online activity and reading comprehension. They also showed the positive attitudes than group who used PC in online extensive reading.

Besides the benefits of digital reading, it cannot be denied that digital reading also has several weaknesses. A number of studies revealed several obstacles and critiques of digital reading. Reading with the long duration on electronic screens can be tiring and potentially more distracting (Milliner \& Cote, 2015). Huang (2013) also revealed that students complained about "tiring eyes," when they had to read long texts on their mobile phones. Furthermore, the participants in Mesureur's (2013) study also grumbled that interruptions from some notifications prevented them to focus on digital book for long time.

Regarding to the benefits and critiques on digital reading, the current study is purposed to highlight the students' perception toward the implementation of extensive reading using mobile device. In other words, this research aims at answering the following research questions, "how are the students' responses toward extensive reading practice?" and "how are the students' perceptions about digital reading?".

Since this is the first time for students to read extensively using the mobile devices as part of the reading course, the lecturer guided them gradually. The result of this study is expected to benefit the extensive reading practice through digital reading and minimize the obstacles in applying it.

\section{METHOD}

This current study employed a qualitative approach and aimed at presenting the students' responses on extensive reading practice and their perceptions on digital reading related to extensive reading. 33 students of the second semester who take Reading 2 course in English Education Department, Universitas Islam Malang, participated in this study. All participants used e-books to apply extensive reading. They chose the books based on their preferences and level. They regularly consulted to the lecturer about the books that suited their level, the number of pages they have to read, and the progress of their reading.

The students should read at least one book or stories collection and record their reading progress through reading log. Reading log is aimed to record the number of pages that students read in a day, list of new vocabularies found in the book, and the summary of the text read in a day. At the end of semester, the students must submit their reading log and reading report about the book summary and book review.

\section{2|ENGLISH EDUCATION}

Journal of English Teaching and Research 
After half semester implementation of extensive reading using mobile device, the participants were interviewed through open-ended questions, "what kinds of book that you read?", "what is your opinion about extensive reading activity?", "how is your perception toward digital reading?", and "do you find any difficulties while reading through mobile device?".

Afterward, the talking data were transcribed and interpreted repetitively through descriptive analysis and it was specified through series of methodology such as (1) listening to the talking data, (2) communicating the talking data with an interpretative meaning, and (3) (re)constructing the talking data (Creswell and Poth, 2018).

\section{RESULTS AND DISCUSSION}

The findings of this study are presented based on the result of interview to the participants. They were classified into students' responses on extensive reading practice and students' perception on digital reading.

\section{The Students' Responses on Extensive Reading Practice}

Related to the extensive reading practice, the students can read any texts or books based on their preferences. The result of interview showed that most students preferred to read about romance, while other stated that they read about action, science fiction, fantasy, fairy tale, folktale, fable, mystery, thriller, comedy, biography and motivation. Some of the students' responses were presented below:

I read the book about love story, romance.

The book is about action, because it's challenging for me.

--.

The book is Alice adventure in wonderland, so it's about adventure and fiction. $-\cdot-$

I love reading novel, but it's too difficult for me. So, I choose fairytale.

The book is about mystery.

In line with Day and Bamford (1998), in extensive reading practice, the students must choose the text or book personally by themselves based on their interests. It is expected that the students will have the reading habit, because they find pleasant while reading the book.

Students' responses on extensive reading practice were recorded during interview process. All the participants showed positive attitude on extensive reading practice. As this was their first experience, some students faced problems to decide the book that suited their level. Therefore, they changed the book for some times. But, after discussing with the lecturer, they could decide the book they wanted.

The students claimed that extensive reading allowed them to learn new vocabularies, spelling, improve speed in reading, develop writing skill, spend free time usefully, improve other skills in English, and significantly enjoy reading the books. Some of their responses were documented below: 
By reading more, I learn about grammar, spelling, and vocabularies.

$---$

I'm very lucky to do extensive reading, because through this activity I can find joy while reading, learn new vocabularies, even improve my writing skill.

This activity is useful for me, because I get many new vocabularies from reading and I can implement those vocabularies in speaking and writing.

Extensive reading gives me some benefits like learning new vocabularies, improving the reading speed, and implementing the new vocabularies in speaking.

It's useful for me to spend my free time, I know about new vocabularies, and enjoy reading the book.

$---$

I learn from the book that wake up in the morning, sleep earlier, and eat healthy food are good for me, I also get so many vocabularies that I don't know.

Those findings supported the related previous study by Anderson, Wilson and Fielding (1988) who believed that extensive reading would improve oral fluency, vocabularies, as well as general information. All the participants in this study implemented extensive reading using their mobile phones. The students, regularly, consulted to the lecturer about e-book that suited them, the number of pages that they have to read, and the progress of their reading. If the texts chosen were around 30-50 pages, the lecturer, then, asked the students to read more texts or books. This is according to Stanley (2005), who argued that extensive reading involves students reading long texts or large quantities for general understanding, with the intention of enjoying the texts.

The students must record their reading progress through reading log. Reading log consists of day/ date, text or book title, the author, number of pages, new vocabularies, and summary. Reading log is aimed to record the number of pages that students read in a day, list of new vocabularies they found in the book, and the summary of the text being read in a day. Twice in a week, the lecturer checked the students' reading log, while showing their reading log, they were asked to retell the story that they have read in front of the lecturer. Through this activity, the students were expected to develop other skills in English. As a number of researchers have recognized that extensive reading could contribute to the language development, from reading proficiency (Beglar\& Hunt, 2014; Robb \& Kano, 2013), vocabulary knowledge (Beglar\& Hunt, 2014; Day \& Bamford, 1998; Krashen, 2004), oral skills (Cho \& Krashen, 1994) and also writing skills (Krashen, 2004).

\section{The Students' Perception on Digital Reading}

Regarding on students' perception about the use of digital reading in extensive reading practice, all participants gave the positive responses. They shared that ebooks were practical, flexible, easy, and most of them were free. Moreover, digital reading offered a large number selection of books. Some of the students' voices were presented as follows:

\section{4|ENGLISH EDUCATION}

Journal of English Teaching and Research 
When I use an e-book to read, it makes me easy, because I can read anywhere. I just need my phone to read. I can also open the dictionary when I find difficult words.

I read using e-book because it's simple, I don't need to go to the library, I don't need to buy a book, so I can save more money, because e-book is free.

---

I can choose any books that I want through e-books, and most of them are free.

With e-book, I don't spend more money to read and I can read the book anywhere and anytime.

I choose e-book because I find it very easy to pick any books that I want. Nowadays, we always bring mobile phone anywhere, so it's easy to read through mobile phone.

I think e-book is very practice, because I can read everywhere through the mobile phone, and we don't need to pay more for it.

The students' responses were in line with Facer, Joiner, Stanton, Reid, Hull and Kirk (2004), who stated that mobile devices benefit students with their portability and versatility in promoting the student-centered learning.Digital reading allowed the students to take advantage of portability and flexibility that mobile device offered (Milliner \& Cote, 2015). In addition, Huang (2013) argued that e-book let the students read anytime, as the online library was never closed, and the availability of online dictionaries enabled them to read more.

In addition, the students pointed out that mobile device offered the practicality, easiness, and affordances in implementing extensive reading. As they applied ebooks to read, whenever and wherever they had free time, they would continue their reading immediately. More of students' voices were documented as follows:

An e-book is practical which can be brought everywhere.

E-book is more affordable than printed book.

$--$

I use e-books because it's very effective. I don't have to carrying books even though it has a lot of pages. I don't need to go to book store, I only need to download it.

It is really efficient for me and I can download it using mobile data or Wi-Fi. I don't have to spend money for buying the book.

$--$

I don't need to bring a book wherever I go, I just need to hold my mobile phone to search some novels through internet. It is simpler than printed book. 
I think reading through e-book is more comfortable and practical. With $e$ books, we can read anywhere without having to carry books.

This is in line with Huang (2013), who found out that e-books benefit the readers with its practicality, easiness, portability, as well as the low cost. The interview session also recorded the participants' comments about the challenges they faced while applying digital reading in extensive reading practice. The students shared different opinions about them. Some of their voices were documented below.

I don't find any weaknesses when I read using e-book, I just think that e-book makes me easy to read for spending my free time.

When we use e-book, it means that we read using mobile phone and our eyes are easily to get tired. It makes us difficult to focus on the reading. But, I still choose $e$-book because I can find so many book choices that suited me for free.

The weakness of e-book is sometimes if I turn on my mobile data, some chats will show on the screen and it distracted me.

$---$

If I read an e-book for long time, it can hurt my eyes, maybe because the mobile phone light is too bright.

Reading through e-book doesn't give any trouble for me.

Some students argued that digital reading brought some challenges for them, including eyestrain and disruptions. A number of studies revealed that digital reading could cause some obstacles and deterrents. Participants in Huang's (2013) study complained about "tired eyes" when they read on their mobile phones for long periods of time. Furthermore, interruptions from email banners and notifications prevented the students to focus on digital books for a long time (Mesureur, 2013). Knowing these challenges as digital reading critiques, however, those consequences were not recorded by numerous other studies (Milliner and Cote, 2015).

Students were aware that reading extensively needed more books and time consuming. They did not feel burdensome to read long texts or more books because they found pleasant reading their self-choice books which fitted their level. The main goal of extensive reading, therefore, is to develop a reading habit and grow the joyfulness in reading (Day and Bamford, 1998). Digital reading is the best option to implement extensive reading effectively. Digital reading allowed the readers to read without constraints of time, space, and condition. Having all day long access to online library enabled the readers to obtain any e-books they wanted and started reading immediately (Huang, 2013).

It is undeniable that digital reading emerged both strengths and critiques for readers. Most participants, however, showed the positive attitudes toward the digital reading, despite its weaknesses. The main reason was the benefits of digital 
reading portrayed a significant role in their success to implement extensive reading. Practicality, portability, accessibility, and affordances were more dominant than eye fatigue and unwarranted distractions. The critiques of reading digitally admittedly present formidable obstacles, yet the benefits of a digital approach outweigh these shortcomings (Milliner and Cote, 2015). In line with this, some participants who faced the disruptions of digital reading convinced themselves that the benefits of digital reading were much more worthy than its weaknesses.

\section{CONCLUSION}

Mobile-assisted on extensive reading offered the readers more opportunities to read. Its practicality, portability, flexibility, accessibility, and affordances let the students applied extensive reading successfully. The reading log helped them to record their last reading progress, memorize the new vocabularies, even develop writing skill. As students regulary reported their reading progress and retold their books, they could improve their speaking skill as well. In the beginning, the students found difficulties to choose the books that fitted their levels. The minimum information on how to access the online libraries might be the reason. Therefore, presenting lists of accessible e-books or online libraries before they started reading may solve this problem.

It is true that digital reading gave some challenges for readers, despite its major benefits. Eyestrain and online distractions are some obstacles to apply digital reading. However, most participants argued that they could minimize the troubles. Since they knew the huge advantages offered by digital reading, including practical device, flexible time and place, affordable cost, and accessible sources, those shortcomings were not significant. The current research findings supported the related previous researches that the integration of technology resources and language teaching and learning may affect the language learners' progress significantly.

Since mobile devices need internet connection to activate their major functions, this can be the limitation of the study, as not all areas and learners can apply them maximally. The future researchers can consider whether all levels of language learners are able to apply the digital reading to extensive reading practice. Moreover, extensive reading is a permanent practice, thus, half semester implementation may not have a significant influence to the learners, therefore, the students should continue this practice for a longer period. The well-designed program for extensive reading practice with digital reading is highly recommended for further studies.

\section{ACKNOWLEDGMENT}

The researcher would like to express the deep and sincere gratitude to LPPM Unisma as the funder of this current research, and to English Education Department, Faculty of Teacher Training and Education, Unisma Malang as the location of the research. 


\section{REFERENCES}

Anderson, R. C., Wilson, P. T. \& Fielding, I.G. (1988). Growth in reading and how children spend their time outside of school. Reading Research Quarterly, 23(3): 285-303.

Beglar, D., \& Hunt, A. (2014). Pleasure reading and reading rate gains. Reading in a Foreign Language, 26 (01): 29-48.

Cho, K., \& Krashen, S. (1994). Acquisition of Vocabulary from the Sweet Valley Kids Series: Adult ESL Acquisition. Journal of Reading, 37(8): 662-667.

Retrieved from https://pdfs.semanticscholar.org/513b/a2ea81ba48b8cbcd4826526989 7e4bc3ed7b.pdf

Creswell, J. W., \& Poth, C. N. (2018). Qualitative inquiry \& research design: Choosing among five approaches (Fourth edition). Los Angeles: SAGE.

Day, R., \& Bamford, J. (1998). Extensive reading in the second language classroom. New York: Cambridge University Press.

Facer, K., Joiner, R., Stanton, D., Reid, J., Hull, R., \& Kirk, D. (2004). Savannah: mobile gaming and learning? Journal of Computer Assisted Learning, 20(6), 399409. https://doi.org/10.1111/j.1365-2729.2004.00105.x

Huang, H. (2013). E-reading and E-discussion: EFL learners' perceptions of an E-book reading program. Computer Assisted Language Learning, 26(3): 258-281.

Krashen, S. (2004). The power of reading: Insights from the research. Westport, Conn: Libraries Unlimited. Retrieved from https://www.scribd.com/doc/232812845/Stephen-D-Krashen-thePower-of-Reading-Insight.

Lin, C. C. (2014). Learning english reading in a mobile-assisted extensive reading program. Computers \& Education: An International Journal. 4859.

Mesureur, G. (2013). An evaluation of ESL reading efficiency and motivation using E-book vs. printed book. In S. Miles \& M. Brierley (Eds.), Extensive Reading World Congress Proceedings (pp. 280-290). Seoul: Extensive Reading Foundation.

Mikulecky, B. S. (2008). Teaching reading in a second language. London: Pearson Education, Inc.

Milliner, B. \& Cote, T. (2015). Mobile-based extensive reading: an investigation into reluctant readers. International Journal of Computer-Assisted Language Learning and Teaching. 5(4): 1-15. https://doi.org/10.4018/IJCALLT.2015100101

Robb, T., \& Kano, M. (2013). Effective extensive reading outside the classroom: A large-scale experiment. Reading in a Foreign Language, 25(2): 234-247.

Safaeia, L.A. \&Bulca, M. (2013). Extensive reading and creative practices. Procedia Social and Behavioral Sciences. 70(2013): 592 597.https://doi.org/10.1016/j.sbspro.2013.01.097

Stanley, G. (2005). Extensive Reading. Retrieved from https://www.teachingenglish.org.uk/article/extensive-reading. 